\title{
Ethnogeographic features of nutrition as a key factor in the development of iron deficiency anemia in the Bukhara region
}

\author{
Akhmedova Dilfuza RAKHMATOVNA \\ Tashkent Pediatric Medical Institute, Department of Obstetrics and Gynecology, with pediatric gynecology, Tashkent, Republic of Uzbekistan \\ Corresponding author's Email: samira17-2007@mail.ru
}

\section{ABSTRACT}

Introduction. Ecological disasters, industrial pollution, and poor nutrition lead to significant changes in the content of microelements (MEs) in food and, as a consequence, in the human body, while toxic MEs accumulate, displacing essential ones. Iron deficiency anemia refers to biogeochemical poly-microelementosis. For the prevention and treatment of iron deficiency anemia (IDA), drugs containing microelements are used along with traditional methods of treatment. Aim. This study aimed to investigate the nutritional characteristics and the ME content in the diet in order to clarify the etiology of IDA, the role of microelementosis in its development, and to also identify indicators of red blood parameters in families living in the Qorovulbozor district of the Bukhara region. Methods. Ten families were examined, each consisting of a husband, a wife, and female children. In order to facilitate the analysis of the results obtained, the husbands and wives selected for examination from those were aged between 30 and 45 with daughters from 12-17 years old. The content of MEs in erythrocytes and blood serum, in tap water, and in irrigation ditch (arch) water was determined. Results. A relatively favorable picture was observed only in men, while 1-3 degree IDA was observed with almost the same frequency in both mothers (75-78.5\%) and their daughters (20-21.4\%), respectively. Daily nutrition was roughly estimated by dividing the volume of food consumed per week into 7 days and the number of family members. Despite this, iron deficiency turned out to be significant for such products as meat, milk, bread, eggs, and fruit. This served as the basis for convincing the subjects of the need for proper nutrition and the administration of ME containing preparations (Vitrum Prenatal Forte). Conclusion. In order to exclude the entry of toxic MEs into the body, it is advisable to use mineral water for food, especially during pregnancy, instead of tap water. Our findings provide the basis for the need to correct the ME composition of the body with the necessary MEs, not only by increasing the volume and quality of food products, but also by using medications containing MEs.

\author{
Original Article \\ PII: S225199391900027-9 \\ Rec. 05 October 2019 \\ Rev. 24 November 2019 \\ Pub. 25 November 2019
}

\section{Keywords}

Microelements (MEs),

Nutrition,

Family,

Iron deficiency anemia

\section{INTRODUCTION}

According to the researchers, various etiological factors cause iron deficiency anemia (IDA) [1, 2]. Anemia can occur in an environmentally disadvantaged region, on the basis of increased consumption of microelements, impaired iron resorption in the gastrointestinal tract, due to a lack of exogenous MEs, including iron [3, 4].

Environmental disasters, man-made pollution, and improper nutrition lead to significant changes in the ME content in the human body, at the same time toxic MEs accumulate, displacing essential MEs [5]. The level of MEs and their relationship in the body organs depend on the degree of blood supply, peculiarities of functional activity and available pathologies. Thus, loss of iron in the blood is one of the most common causes of anemic conditions. Iron deficiency anemia refers to polymicroelementoses (pathological processes caused by deficiency, excess and imbalance of microelements in the body) of biogeochemical nature. Along with traditional methods of treatment, ME-containing medications are used to prevent and treat IDA [6, 7].

It is known that certain regions have their own specifics for the ME content that distinguishes them from others [8]. Hence the traditional approach to the prevention and treatment of IDA is not justified. Literature data indicates the need to develop ME-containing preparations for certain regions based on the ME content in the air, soil and water [9]. This research is devoted to the study of ME blood composition in families living in the Qorovulbozor district of the Bukhara region, where a large oil refinery is located, which has a technogenic impact on the region. In addition, families' food rations were first studied with an estimate of the ME intake. The data obtained will help to clarify the pathogenesis of IDA development in adolescent girls from the perspective of microelementosis and to develop a reasonable set of therapeutic and preventive measures. 
The research is aimed at studying the nutritional characteristics, the content of microelements in the food rations in order to clarify the IDA etiology and the role of microelementosis in IDA development by investigating red blood cell parameters in families living in the Qorovulbozor district of the Bukhara region.

\section{MATERIAL AND METHODS}

Examinations covered ten families, each consisting of a husband, wife, and female children. In order to facilitate the analysis of the results obtained, parents aged between 30-45 were selected for the research, with their daughters aged between 12 and 17. We studied their medical background, previous diseases that can affect the ME composition of blood, $\mathrm{Hb}$ concentration, RBC count, blood color index and ESR results. Families were identical in terms of social background - employees and workers, as well as in medical background and previous diseases. Family members with acute inflammatory diseases or disease recurrences were excluded from the analysis. The content of ME was determined in erythrocytes and blood serum, in tap water, and in irrigation ditch (arch) water. Since the main source of ME supply in the human body is food, we studied daily food rations in families and calculated the daily ME requirement depending on the food assortment. The standard indicators of the ME content in $100 \mathrm{~g}$ of the product were the basis for comparison [10]. Following the results of this analysis, we made recommendations for proper nutrition and prescribed Vitrum preparations containing microelements.

\section{Statistical analysis}

The data obtained during the study was subjected to statistical processing on a Pentium-V personal computer using the Microsoft Office Excel-2003 software package, including the use of built-in statistical processing functions. We used methods of variational parametric and nonparametric statistics with calculation of the arithmetic mean of the studied indicator $(\mathrm{M})$, standard deviation), standard error of the mean (m), relative values (frequency, \%), the statistical significance of the measurements obtained when comparing the average values was determined by the criterion Student $(t)$ with the calculation of the probability of error $(P)$ when checking the normality of the distribution (by the excess measure) and the equality of the general variances ( $F$ Fisher's test). For statistically significant changes, a confidence level of $\mathrm{P}<0.05$ was taken

\section{Ethical approval}

The review board and ethics committee of Tashkent Pediatric Medical Institute approved the study protocol and informed consents were taken from all the participants.

\section{RESULTS AND DISCUSSION}

Table 1 presents the results of a general blood test in family members before and after treatment. As can be seen from the table, IDA of varying severity was found in the examined population. Thus, stage 1 of the IDA was not observed in girls, while stage 2 was observed in $78.5 \%$ and stage 3 was present in $21.4 \%$ of girls; in their mothers we observed stage 1 of the IDA in 5\%, stage 2 in 75\%, and stage 3 in $20 \%$ of subjects, respectively; in their fathers we evidenced stage 1 in 65\%, stage 2 in 35\% of men, respectively, while stage 3 was found in none of the subjects Thus, a relatively favorable picture was observed only in men. Stage 2 and stage 3 of the IDA were observed with almost the same frequency in both mothers and their daughters: 75\% (78.5\%), and 20\% (21.4\%), respectively. Thus, IDA develops in children from an early age. The study of the food rations showed that in almost all families there is a shortage in the consumption of basic food products compared to the norm. This is confirmed by the presence of anemia in the male part of the examined subjects. The data on daily food requirement and actual consumption of food products in the studied families is given in Table 2. On short notice, it should be mentioned that the volume of consumption per week was roughly estimated and divided into 7 days and the number of family members. Despite this, the deficiency turned out to be significant for some products, such as meat, milk, bread, eggs, and fruit. This served as the basis for convincing the subjects of the need for proper nutrition and prescription of Vitrum Prenatal Forte preparations containing microelements.

Next, we studied the shortage of ME intake into the body with food based on the data obtained. Standard data on ME content in 100 grams of a product is given in Table 3 based on the indicators specified in [10].

When comparing the actual consumption of food products (14 basic ones) with the norms of consumption and the ME content in these food products, a significant shortage of both essential and conditionally essential MEs was found. Due to the fact that less food is consumed, fewer toxic MEs entered the body accordingly. The same can also be attributed to pregnant women, since their questioning gave the same results of $\mathrm{ME}$ consumption shortage. It is noteworthy that the water used in food contains toxic $\mathrm{MEs}$ such as $\mathrm{Be}, \mathrm{Cd}, \mathrm{Hg}$, $\mathrm{Al}$, and $\mathrm{Pb}$. Normally, toxic microelements should not be found in water. The fact is that they have the ability to competitively bind to proteins, enzymes, and other vital substances and distort their function, displacing essential and conditionally essential microelements [11]. The foregoing is one of the reasons for the development of not only anemia, but also of other diseases present in the examined population. 
Table 1. Red blood cell parameters in family members with complicated IDA

\begin{tabular}{|c|c|c|c|c|c|c|}
\hline \multirow{3}{*}{ Parameter } & \multicolumn{6}{|c|}{ Family with IDA, n=10 } \\
\hline & \multicolumn{2}{|c|}{ In daughters, $n=10$} & \multicolumn{2}{|c|}{ In mothers, $n=10$} & \multicolumn{2}{|c|}{ In fathers, $n=10$} \\
\hline & $\begin{array}{c}\text { Pretreatment } \\
\text { parameters }\end{array}$ & $\begin{array}{c}\text { Follow-up } \\
\text { control }\end{array}$ & $\begin{array}{l}\text { Pretreatment } \\
\text { parameters }\end{array}$ & $\begin{array}{l}\text { Follow-up } \\
\text { control }\end{array}$ & $\begin{array}{l}\text { Pretreatment } \\
\text { parameters }\end{array}$ & $\begin{array}{c}\text { Follow-up } \\
\text { control }\end{array}$ \\
\hline $\mathrm{Hb}, \mathrm{g} / \mathrm{l}$ & $79.8 \pm 3.4^{* *}$ & $114.5 \pm 3.6$ & $81.8 \pm 3.5^{* *}$ & $120.4 \pm 4.4$ & $102.2 \pm 3.8^{* *}$ & $130.2 \pm 4.6$ \\
\hline $\mathrm{RBC}, 10 \cdot 12 \mathrm{~g} / \mathrm{l}$ & $3.2 \pm 0.4^{*}$ & $3.6 \pm 0.6$ & $3.3 \pm 0.2^{*}$ & $4.0 \pm 0.8$ & $3.7 \pm 0.5^{*}$ & $4.6 \pm 1.0$ \\
\hline Color index & $0.8 \pm 0.03^{*}$ & $0.9 \pm 0.04$ & $0.8 \pm 0.06^{*}$ & $0.9 \pm 0.1$ & $0.9 \pm 0.08$ & $0.9 \pm 0.2$ \\
\hline ESR & $4.0 \pm 1.1$ & $4.2 \pm 1.2$ & $4.8 \pm 1.4$ & $5.7 \pm 2.5$ & $4.2 \pm 1.3$ & $4.3 \pm 2.2$ \\
\hline
\end{tabular}

Note: ${ }^{*} \mathrm{P}<0.05$ and ${ }^{* *} \mathrm{P}<0.01$ compared to the parameters in males. IDA= iron deficiency anemia; Hb= hemoglobin; RBC= Red blood cell and $\mathrm{ESR}=$ erythrocyte sedimentation rate.

Table 2. The daily food requirement and actual consumption of food products in the examined families living in the Qorovulbozor district (Bukhara region, Uzbekistan)

\begin{tabular}{lccc} 
Food products & $\begin{array}{c}\text { Standard daily } \\
\text { requirement }\end{array}$ & $\begin{array}{c}\text { Food consumption } \\
\text { in a family with IDA }\end{array}$ & $\begin{array}{c}\text { Shortage in consumption } \\
\text { of food products }\end{array}$ \\
\hline Meat & $150 \mathrm{~g}$ & $90 \mathrm{~g}$ & $60 \mathrm{~g}$ \\
Milk & $500 \mathrm{ml}$ & $290 \mathrm{~g}$ & $210 \mathrm{~g}$ \\
Rice & $50 \mathrm{~g}$ & $40 \mathrm{~g}$ & $10 \mathrm{~g}$ \\
Bread & $250-300 \mathrm{~g}$ & $150 \mathrm{~g}$ & $150 \mathrm{~g}$ \\
Chocolate & $40 \mathrm{~g}$ & $10 \mathrm{~g}$ & $30 \mathrm{~g}$ \\
Eggs & $1-2(120 \mathrm{~g})$ & $60 \mathrm{~g}$ & $60 \mathrm{~g}$ \\
Potato & $100 \mathrm{~g}$ & $100 \mathrm{~g}$ & $0 \mathrm{~g}$ \\
Onion & $150 \mathrm{~g}$ & $100 \mathrm{~g}$ & $50 \mathrm{~g}$ \\
Fruit & $200-250 \mathrm{~g}$ & $100 \mathrm{~g}$ & $150 \mathrm{~g}$ \\
Cabbage & $300-600 \mathrm{~g}$ & $200 \mathrm{~g}$ & $400 \mathrm{~g}$ \\
Carrot & $50-100 \mathrm{~g}$ & $80 \mathrm{~g}$ & $20 \mathrm{~g}$ \\
Beet & $100-150 \mathrm{~g}$ & $50 \mathrm{~g}$ & $100 \mathrm{~g}$ \\
Tomato & $200-300 \mathrm{~g}$ & $100 \mathrm{~g}$ & $200 \mathrm{~g}$ \\
Honey & $80-100 \mathrm{~g}$ & $40 \mathrm{~g}$ & $60 \mathrm{~g}$ \\
\hline
\end{tabular}

IDA= iron deficiency anemia

Table 3. Standard indicators of ME content in $100 \mathrm{~g}$ of a product [10]

\begin{tabular}{|c|c|c|c|c|c|c|c|c|c|c|c|c|c|c|c|}
\hline \multirow{2}{*}{ ME } & \multicolumn{10}{|c|}{ Essential microelements } & \multicolumn{5}{|c|}{ Toxic microelements } \\
\hline & $\mathrm{Cr}$ & Mn & Fe & Co & $\mathrm{Cu}$ & Zn & Se & Mo & I & $\mathbf{N i}$ & $\mathrm{Be}$ & Al & Cd & $\mathrm{Hg}$ & $\mathbf{P b}$ \\
\hline Food products & \multicolumn{15}{|c|}{ Minerals in $100 \mathrm{~g}$ of a product } \\
\hline Meat & 8.7 & 35.0 & 2090 & 6.0 & 238 & 2820 & - & 9.0 & 2.7 & 5.5 & - & - & - & - & - \\
\hline Milk & 2 & 6 & 67 & 0.8 & 12 & 400 & 2.0 & 5.0 & 9.0 & - & - & 50 & - & - & - \\
\hline Rice & 2.8 & 3630 & 2090 & 6.9 & 560 & 1800 & 20.0 & 26.7 & 2.3 & 51.6 & - & 912 & - & - & - \\
\hline Beans & 10.0 & 1340 & 5940 & 18.7 & 580 & 3210 & 24.9 & 39.4 & 12.1 & 173.2 & & 640 & & & \\
\hline Buckwheat & 6.0 & 1760 & 8270 & 3.6 & 660 & 2770 & - & 38.5 & 5.1 & - & - & - & - & - & - \\
\hline Green peas & 9.0 & 1750 & 6800 & 13.1 & 750 & 3180 & 13.1 & 84.2 & 5.1 & 246.6 & - & 1180 & - & - & - \\
\hline Onion & 2 & 230 & 800 & 5 & 85 & 850 & - & - & 3.0 & 3.0 & - & 400 & - & - & - \\
\hline Bread & 4.5 & 1470 & 3900 & 3.0 & 290 & 1850 & - & 20.4 & - & 20.0 & - & 1400 & - & - & - \\
\hline Potato & 10 & 170 & 900 & 5 & 140 & 360 & - & 8.0 & 5.0 & 5.0 & - & 860 & - & - & - \\
\hline Aubergine & - & 210 & 400 & 1 & 135 & 290 & - & 10.0 & 2.0 & - & - & 815 & - & - & - \\
\hline Cabbage & 5 & 170 & 600 & 3 & 75 & 400 & - & 10.0 & 3.0 & 15.0 & - & 570 & - & - & - \\
\hline Tomato & 5 & 140 & 900 & 6 & 110 & 200 & - & 7.0 & 2.0 & 13.0 & - & - & - & - & - \\
\hline Cucumber & 6 & 180 & 600 & 1 & 100 & 215 & - & 1.0 & 3.0 & - & - & 425 & - & - & - \\
\hline Beet & 20 & 660 & 1400 & 2 & 140 & 425 & - & 10.0 & 7.0 & 14.0 & - & - & - & - & - \\
\hline Carrot & 3 & 200 & 700 & 2 & 80 & 400 & - & 20.0 & 5.0 & 6.0 & - & 323 & - & - & - \\
\hline Pumpkin & - & 40 & 400 & 1 & 180 & 240 & - & - & 1.0 & - & - & - & - & - & - \\
\hline Chocolate & - & 3100 & 5000 & - & 495 & - & - & - & 5.5 & - & - & - & - & - & - \\
\hline Honey & - & 34 & 800 & 0.3 & 59 & 94 & - & - & 2.0 & - & - & - & - & - & - \\
\hline Kefir & 2 & 6 & 80 & 1 & 10 & 400 & 2.0 & 5.0 & 9.0 & - & - & - & - & - & - \\
\hline Grapes & 3 & 90 & 600 & 2 & 80 & 91 & - & 3.0 & 8.0 & 16.0 & - & 380 & - & - & - \\
\hline Eggs & 4 & 29 & 2500 & 10 & 83 & 1110 & - & 6.0 & 20.0 & - & - & - & - & - & - \\
\hline Pear & - & 65 & 2300 & 10 & 120 & 190 & - & 5.0 & 1.0 & 17.0 & - & - & - & - & - \\
\hline Plum & 4 & 110 & 500 & 1 & 87 & 100 & - & 8.0 & 4.0 & 15.0 & - & - & - & - & - \\
\hline Melon & - & 35 & 1000 & 2 & 47 & 90 & - & - & 2.0 & - & - & - & - & - & - \\
\hline Semolina & 4.3 & 440 & 960 & 25 & 70 & 590 & - & 11.3 & - & 11.5 & - & 570 & - & - & - \\
\hline Peach & 14 & 140 & 600 & - & 50 & 100 & - & - & 2.0 & 4.0 & - & 650 & - & - & - \\
\hline Fish & 55 & 60 & 1000 & 20 & 60 & 450 & - & 4.0 & 5.0 & 6.0 & - & - & - & - & - \\
\hline Walnut & - & 1900 & 2300 & 7.3 & 527 & 2570 & - & - & 3.1 & - & - & - & - & - & - \\
\hline
\end{tabular}




\section{CONCLUSION}

In order to exclude the entry of toxic ME into the human body, it is advisable to use mineral water for food, especially during pregnancy, instead of tap water. Our findings provide the basis for the need to correct the ME composition of the human body with the necessary MEs, not only by increasing the volume and quality of food products, but also by using medications containing MEs. This is evidenced by the indicators of ME blood composition, both in the studied families and in pregnant women.

\section{DECLARATIONS}

\section{Acknowledgements}

This work was supported by Tashkent Pediatric Medical Institute, Tashkent City, Uzbekistan.

\section{Authors' contributions}

All authors contributed equally to this work.

\section{Competing interests}

The authors declare that they have no competing interests.

\section{REFERENCES}

1. Podzolkova, N.M., Nesterova, A.A., Nazarova, S.V., Sheveleva, T.V. Iron deficiency anemia in pregnant women. Russian Medical Journal, 2003, 5, 326-331. [In Russian; Железодефицитная анемия беременных / Н.М. Подзолкова, А.А. Нестерова, С.В. Назарова, Т.В. Шевелева // Русский медицинский журнал.-М., 2003.-№ 5.- 326-331.] Google Scholar

2. Kayupova N.A., Abdykalykova B.I. The influence of environmental factors on the state of the feto-placental system and immunity in pregnant women with anemia from the Aral region. Central Asian Medical Journal, 1998, 4(6), 331-335. [In Russian; Каюпова Н.А., Абдыкалыкова Б.И. Влияние факторов окружающей среды на состояние фето-планцентарной системы и иммунитета у беременных женщин с анемией из региона Арала // Централ.-аз. мед. журнал. - 1998. - Т.1У.-№6. - С. 331-335.]

3. Amonov I.I. Features of the microelement composition of blood in children born to mothers with iron deficiency anemia. Pediatrics, 2004, 1, 18-22. [In Russian; Амонов И.И. Особенности микроэлементного состава крови у детей, рожденных от матерей с железодефицитной анемией // Педиатрия (узб.). - Т., 2004. - №1. - С. 18-22.]

4. Kurbanov D.D. Microelementoses: eco-characterization, ways to prevent it. News of Dermatovenereology and Reproductive Health, 2008, 4, 40-42. [In Russian; Курбанов Д. Д. Микроэлементозы: экохарактеристика, пути ее предупреждения // Новости дерматовенерологии и репродуктивного здоровья. - Т., 2008. - N4. - С. 40-42.]

5. Anikina L.V., Nikitina L.P. Selenium. EcologY, pathology, correction. Chita: Chita State Medical Academy Press 2002. [In Russian; Аникина, Л.В., Никитина Л.П. Селен // Экология, патология, коррекция.- Чита, 2002.- 400 с.] Google Scholar

6. Asadov D.A., Sabirov D.M., Nazhmitdinov A.M., Tagirov Ch.I. Clinical guidelines for screening, prevention and treatment of iron deficiency anemia. News of Dermatovenereology and Reproductive Health, 2004, 3, 5-12. [In Russian; Клиническое руководство по скринингу, профилактике и лечению железодефицитной анемии / Д.А. Асадов, Д.М. Сабиров, А.М. Нажмитдинов, Ч.И. Тагиров // Новости дерматовенерол. и репродукт. здоровья. - Ташкент, 2004. №3. С. 5-12.] Google Scholar

7. Kalaendarov D.K., Ibragimov T.K., Usmanov D.U., Butaeva R. et al. Drug intervention using a balanced diet for the longterm treatment of patients with iron deficiency anemia: scientific publication. Proceedings of the V Congress of Therapists of Kazakhstan (Almaty, June 20-21, 1995), Almaty, 1995. [In Russian; Медикаментозное вмешательство с использованием сбалансированной диеты при длительном лечении больных с железодефицитной анемией : научное издание / Д.К. Калаендаров, Т.К. Ибрагимов, Д.У. Усманов, Р. Бутаева и др // Материалы V съезда терапевтов Казахстана (Алматы, 20-21 июня 1995 г.). - Алматы, 1995. - C. 43.]

8. Gres N. A., Tarasyuk I. V. Microelementoses of a human: actual problems. Medicine, 2006, 3, 37-45. [In Russian; Гресь H. A., Тарасюк И. В. Микроэлементозы человека: актуальные проблемы // Медицина. - 2006. - N3. - С. 37-45.] Google Scholar

9. Boev V.M., Utenina, V.V., Bystrykh V.V., et al. The imbalance of microelements as a factor in environmentally related diseases. Hygiene and Sanitation, 2001, 5: 68. [In Russian; Дисбаланс микроэлементов как фактор экологически обусловленных заболеваний / В.М.Боев, В.В.Утенина, В.В.Быстрых и др. // Гигиена и санитария. - 2001. - №5. - С. 68.] Google Scholar

10. Skurikhin, I.M., Volgarev M.N. (Eds.) Chemical composition of food products. Reference tables for the content of basic nutrients and the energy value of food. Moscow: Agropromizdat, 1987. [In Russian; Химический состав пищевых продуктов // И.М. Скурихин, А.И. Волгарева. - M, 1987. -212 c.] Google Scholar

11. Avtsyn A.P., Zhavoronkov A.A.,. Rish M.A, Strochkova L.S. Human microelements: (etiology, classification, organopathology). Moscow: Medicine, 1991. [In Russian; А.П. Авцын, А.А.Жаворонков, М.А.Риш, Л.С. Строчкова . Микроэлементы человека: (этиология, классификация, органопатология) / - М : Медицина, 1991. - 495 с.] Google Scholar 